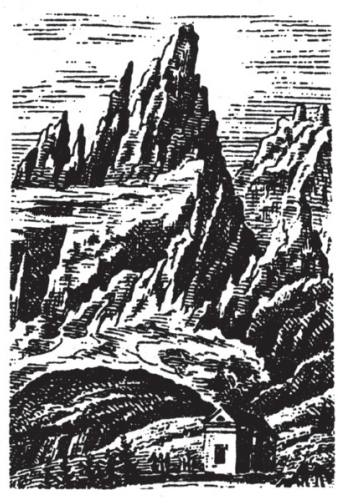

Katarzyna Tałuć

ORCID: 0000-0001-8944-6209

Uniwersytet Śląski w Katowicach

tkat1970@02.pl

katarzyna.taluc@us.edu.pl

DOI: $10.19195 / 2084-4107.12 .18$

\title{
Górska wędrówka w służbie wychowania „nowego” człowieka w dwudziestoleciu międzywojennym
}

Słowa-klucze: góry, turystyka, historia, czasopisma krajoznawczo-turystyczne, czasopisma dla młodzieży, wychowanie

Keywords: mountains, tourism, history, tourist and regional studies journals, journals for young people, education

\section{Mountain hikes in the service of the education of a "new" man in the interwar period}

\section{Summary}

After the end of the First World War and rebirth of the Polish state, one of the most important objectives in visions of social education was the formation of a lasting system of moral concepts of Poles, a system that was the basis of constructing a "new" citizen. Inspirations for actions undertook by Polish teachers and tutors, which were to bring about a strengthening of values like patriotism, 
freedom, friendship, tolerance, respect for work, were ideas promoted by national and international organisations, e.g. League of Nations, International League of New Education, Society of Teachers from Schools and Higher Education Institutions, Polish Teachers' Union or youth organisations of e.g. scouts. Methods of upbringing described in Polish pedagogical literature and applied in practice, which were appreciated by European scholars, included various forms of working with students outside school. These included excursions, trips, hiking camps, also in the mountains. The value of being in the mountains, the effort involved in climbing them, the need to educate a generation of young tourists respecting the natural environment were discussed in guides for tutors, teachers, regional studies specialists, and in the tourist press. The author examines selected publications, primarily tourist press addressed to young readers (Orli Lot, Młody Krajoznawca Ślaski, Młody Taternik) in order to reconstruct the means used to functionalise the topic of mountain hikes in the interwar period.

Doświadczenia I wojny światowej pociągnęły za sobą dyskusje obejmujące zagadnienia wychowawczo-oświatowe, których celem było przede wszystkim sformułowanie wskazówek ułatwiających pedagogom i nauczycielom pracę z kolejnymi pokoleniami młodych ludzi w duchu ogólnohumanistycznych wartości. Idee te propagowano na Międzynarodowych Kongresach Ligi Nowego Wychowania, Międzynarodowych Kongresach Wychowania Moralnego, Międzynarodowych Kongresach Szkół Średnich oraz na zjazdach i kongresach pedagogicznych organizowanych na przykład przez Związek Nauczycielstwa Polskiego' ${ }^{1}$. Uczestnicy owych spotkań byli zgodni co do tego, że największą rolę w kształceniu nowego człowieka na miarę powojennej epoki odgrywają rodzina i szkoła. W Polsce działacze, doceniając idee wychowania społeczno-moralnego postulowane przez pedagogów z USA, Francji czy Niemiec, jednocześnie wskazywali na specyficzną sytuację polskiego narodu, co ich zdaniem wiązało się z koniecznością konstruowania własnych, oryginalnych programów kształcenia. Adaptacja zagranicznych propozycji, jak podkreślał na przykład Bogdan Nawroczyński, winna być zatem podporządkowana historycznie, kulturowo i społecznie ukształtowanym wartościom oraz cechom właściwym danemu narodowi ${ }^{2}$.

Analiza rozwoju myśli pedagogicznej dwudziestolecia międzywojennego pozwala mówić o dwóch głównych stanowiskach dotyczących pożądanych wartości leżących u podstaw aksjologicznego systemu każdego obywatela w odrodzonej Rzeczypospolitej, a zwłaszcza młodych ludzi. Jedno eksponowało wartości chrześcijańskie, religijne, drugie - wartości ogólnohumanistyczne. Obydwa poglądy, charakterystyczne dla dominujących w Polsce orientacji ideowo-politycznych, zgodnie jednak podkreślały konieczność doskonalenia takich cnót, jak: miłość bliźniego, uczciwość, rzetelność, wytrwałość, systematyczność i ofiarność. Różnice zasadzały się jedynie na sposobie definiowania owych wartości. Formacje

${ }^{1}$ Zob.Ł. Kabzińska, Idea wychowania moralno-społecznego w programach Międzynarodowych Kongresów Pedagogicznych okresu międzywojennego, „Warmińsko-Mazurski Kwartalnik Naukowy, Nauki Społeczne" 2013, nr 4, s. 39-66.

2 Zob. B. Nawroczyński, Tempo rozwoju społecznego a zadania wychowawcze pokolenia, „Muzeum” 42, 1927, nr 1-2, s. 25-35; idem, Teoria i praktyka wychowania, „Przegląd Pedagogiczny" 42, 1923, nr 1, s. 3-13. 
rządowe, zwłaszcza po przewrocie majowym, dodatkowo silnie akcentowały cechy pożądane z punktu widzenia interesu państwa, a więc: odpowiedzialność, szacunek dla prawa, odwagę cywilną czy gotowość do poświęcenia się w imię obrony wolności i suwerenności ojczyzny ${ }^{3}$.

Wzorzec osobowościowy kształtowały, jak wspomniano, przede wszystkim dwa środowiska socjalizujące: rodzina i szkoła. Szkoła w dwudziestoleciu międzywojennym w tym zadaniu była wspomagana przez inne instytucje, spośród których można wymienić między innymi towarzystwa, jak Polskie Towarzystwo Krajoznawcze, oraz organizacje, na przykład Związek Harcerstwa Polskiego. Wymienione, tak jak inne stowarzyszenia, w celu propagowania swoich programów, celów, dla jakich zostały powołane, a także aby zjednoczyć swoich członków oraz sympatyków, powoływały do życia tytuły prasowe. Periodyki z lat 1918-1939, zwłaszcza te adresowane do dzieci i młodzieży i klasyfikowane jako prasa szkolna lub pozaszkolna odgrywały istotną rolę w kształtowaniu postaw moralnych, oddziałując na szerokie kręgi młodzieży w duchu ideowo-patriotycznym ${ }^{4}$. Jerzy Jarowiecki podkreślał, że wiele czasopism z tego okresu wspierało realizację celów oświatowych i ,niezależnie od intencji nadawców zawsze wpisywało się w szeroko pojęty proces edukacji na różnych poziomach kształcenia"5.

Celem autorki tekstu jest prezentacja, przy wykorzystaniu narzędzi geokrytyki ${ }^{6}$, sposobów pisania o wędrówkach górskich w opracowaniach o charakterze instruktażowo-metodycznym i w wypowiedziach drukowanych na łamach czasopism krajoznawczo-turystycznych adresowanych do młodego czytelnika. Uwagę skoncentrowano na zabiegach służących sfunkcjonalizowaniu wybranych wypowiedzi, co miało wspomóc proces zarówno wychowania młodego pokolenia w duchu wartości ogólnohumanistycznych, jak i kultywowania postawy służby ojczyźnie. Materiał egzemplifikacyjny zaczerpnięto z następujących czasopism: „Orli Lot. Miesięcznik Krajoznawczy dla Młodzieży” (powstał z „Miesięcznika Krajoznawczego dla Młodzieży"), wydawany jako organ Sekcji Szkół Krajoznawczych oddziału krakowskiego Polskiego Towarzystwa Krajoznawczego w Krakowie w latach 1920-1939 (redaktorem był Leopold Węgrzynowicz ${ }^{7}$ ); „Młody Krajoznawca Śląski. Pisemko Koła Krajoznawczego Gimnazjum Klasycznego w Królewskiej Hucie (Chorzów)”, wydawany w latach 1934-1938 pod redakcją

3 M. Strzelecki, Wizje wychowania społecznego w polskiej myśli politycznej lat 1918-1939, Bydgoszcz 2008, s. 113-141.

${ }^{4}$ O roli czasopism dla młodych czytelników jako narzędzia w propagowaniu ideałów wychowawczych pisała między innymi Irena Socha w Czasopisma dla młodzieży — literatura piękna wychowanie literackie (1918-1939), Katowice 1990, s. 153-155.

5 J. Jarowiecki, Czasopisma dla dzieci i młodzieży oraz prasa młodzieżowa w Polsce w latach 1918-2000, Kraków 2016, s. 8-9.

${ }^{6}$ Zob. E. Rybicka, Geopoetyka. Przestrzeń i miejsce we wspótczesnych teoriach i praktykach literackich, Kraków 2014, s. 92-11, 117-122.

${ }^{7}$ Leopold Węgrzynowicz kierował „Orlim Lotem” od numeru 1 do numeru 8 z 1938 roku, z przerwą w 1924, kiedy na czele miesięcznika stanął Tadeusz Kiełpiński. W 1938 roku miejsce Węgrzynowicza zajął Tadeusz Seweryn, który redagował pismo do wybuchu II wojny światowej. 
Józefa Jakubowskiego; „Młody Taternik. Ilustrowany Dwutygodnik Regionalny Szkolnej Młodzieży Podhalańskiej”, wychodzący w latach 1934-1935 pod redakcją Edwarda Kłonieckiego i Piotra Farona. Wybrano jeden tytuł ogólnopolski i dwa regionalne, przy czym „Orli Lot” i „Młody Krajoznawca Śląski” wyróżniały się trwałością i wysokim poziomem redagowania. „Młody Taternik...” znalazł się w kręgu zainteresowania z powodu miejsca wydawania, które w naturalny sposób predestynowało pismo do poruszania problematyki górskiej.

Jedną z płaszczyzn edukacji i jednocześnie formowania osobowości w dwudziestoleciu międzywojennym stało się krajoznawstwo i wyrosły na jego gruncie regionalizm ${ }^{8}$. Polskie Towarzystwo Krajoznawcze od początku istnienia silnie akcentowało rolę wycieczek w realizacji podstawowych celów organizacji, czyli szerzenia wśród społeczeństwa wiedzy o ojczystej przyrodzie, kulturze, a przez to rozbudzania uczucia przywiązania i odpowiedzialności za los swojej krainy i jej mieszkańców. W ustawie PTK z 1906 roku o wycieczkach organizowanych przez „specjalistów poszczególnych gałęzi krajoznawstwa”, między innymi dla młodzieży, traktowały pierwsze dwa punkty drugiego paragrafu'. Wycieczki pozostały jedną z podstawowych form pracy PTK także po odzyskaniu przez Polskę niepodległości, kiedy Towarzystwo dopasowywało swoją organizację do innych polityczno-społeczno-ekonomicznych warunków.

Aleksander Patkowski ${ }^{10}$, jeden z najaktywniejszych w dwudziestoleciu międzywojennym animatorów krajoznawstwa, zainicjował ogólnopolską dyskusję nad regionalizmem rozumianym jako zestaw wytycznych, których realizacja pozwoliłaby na sprawną unifikację ziem tworzących młode państwo, jakim była Rzeczypospolita. Patkowski precyzowanie pojęcia „regionalizm” i nadawanie luźnym myślom, twierdzeniom kształtu programu ściśle skorelował z pracą nauczyciela, zwłaszcza organizacją kursów dla nauczycieli szkół powszechnych, a później $\mathrm{z}$ tworzeniem uniwersytetów regionalnych. W Projekcie organizacji Uniwersytetu Powszechnego imienia Stanistawa Konarskiego dla nauczycielstwa szkót powszechnych $i$ średnich oraz pracowników społecznych i samorzadowych, uzasadniając powołanie do życia tego typu instytucji, pisał o wyjątkowej roli, nawet posłannictwie, nauczyciela:

8 O historii i rozwoju krajoznawstwa i regionalizmu w Polsce w latach międzywojennych ukazały się między innymi następujące publikacje: M. Niewczas, S. Zaborniak, Ł. Szmyd, Historia turystyki w Polsce przed 1939 rokiem, t. 1. Tradycje, prekursorzy, prawo, szlaki i upowszechnianie, Rzeszów 2017; eadem, Historia turystyki w Polsce przed 1939 rokiem, t. 2. Organizacje i stowarzyszenia turystyczne, Rzeszów 2017; E. Chudziński, T. Skoczek, Regionalizm. Idea - ludzie instytucje, Warszawa 2013; A. Lubczyńska, Regionalizm kielecki w latach 1918-1939, Kielce 2008; B. Wysocka, Regionalizm wielkopolski w II Rzeczypospolitej 1919-1939, Poznań 1981.

9 Ustawa Polskiego Towarzystwa Krajoznawczego, Warszawa 1906, s. 2-3, http://bstatuty. pttk.pl/Ustawa_PTK_1906.pdf (dostęp: 2.04.2018).

10 Zob. Z. Wójcik, Aleksander Patkowski - pionier regionalizmu turystyczno-krajoznawczego w Polsce, Radom 2003. 
Nauczyciel szkoły średniej urabiać będzie duszę młodzieży do pracy $\mathrm{w}$ duchu idei państwowej i obywatelskiej, gruntując w młodym pokoleniu wartość i ideę pracy w ogóle, tą samą ideą ożywiony będzie nauczyciel seminarium, czy też szkoły zawodowej [...]. Aktywizm wpoi w duszę człowieka ideę. Ale wartość idei uzależniona jest od intelektu. Umysł pogłębia ideę, zmysł społeczny czyni ją bardziej ludzką. Współrzędnie z wprowadzeniem czynnika aktywnego musi iść praca nad wychowaniem nowego typu nauczyciela, kształcącego duszę młodego pokolenia Polski ${ }^{11}$.

Niecały rok po upublicznieniu Projektu, 12 marca 1924 roku, Patkowski wygłosił w siedzibie PTK referat o regionalizmie, którego treść stała się podstawą artykułu programowego pod tytułem Idee przewodnie regionalizmu, wydrukowanego na łamach „Przeglądu Współczesnego"12. Dla Patkowskiego regionalizm miał za zadanie szerzenie przywiązania do stron rodzinnych i pogłębianie czynnej roli obywatela do pracy zawodowo-społecznej ${ }^{13}$. Jedną z wymienionych metod służących osiągnięciu tak sformułowanych celów było organizowanie wycieczek, obozów, podczas których młodzi ludzie zbieraliby informacje o otaczającym środowisku, lecz także mieliby sposobność „kolekcjonowania” wrażeń doznawanych w trakcie eksploracji przestrzeni.

Cele, jakie w ramach działań oświatowych ruchu krajoznawczego i regionalizmu wytyczono organizatorom i uczestnikom wycieczek, ewoluowały, tak jak zmieniały się w nowej historycznej sytuacji statut PTK i program regionalizmu. W odrodzonej Rzeczypospolitej, a zwłaszcza z chwilą sformalizowania programu regionalizmu, w pracy kół akcentowano bowiem pierwiastek wychowawczy. O zwróceniu uwagi na młodych ludzi jako współpracowników PTK świadczyło powoływanie w 1918 roku w ramach struktury Towarzystwa kół młodzieżowych. Ze sprawozdania PTK za rok 1918 wynika, że w maju powstało Koło Młodzieży Szkolnej, między innymi z sekcją wycieczkową. W tym samym czasie utworzono Koło Młodzieży Rzemieślniczej również posiadające sekcję wycieczkową ${ }^{14}$. W następnych latach podobne koła powoływano do życia przy nowych oddziałach PTK. Do jednych z najaktywniejszych oddziałów należy zaliczyć oddział krakowski, który — zainspirowany pomysłami profesora Ludomira Sawickiego — w 1919 roku utworzył Sekcję Kół Krajoznawczych Młodzieży pod przewodnictwem Leopol-

11 A. Patkowski, Projekt organizacji Uniwersytetu Powszechnego imienia Stanisława Konarskiego dla nauczycielstwa szkół powszechnych i średnich oraz pracowników społecznych i samorzadowych, „Oświata Pozaszkolna” 1923, nr 1, s. 46-47.

12 Zob. A. Patkowski, Idee przewodnie regionalizmu, „Przegląd Współczesny” 11, 1924, nr 30, s. 3-14.

13 Por. ibidem, s. 10-11.

14 Zob. Polskie Towarzystwo Krajoznawcze, Sprawozdanie za rok 1918, s. 8, http://bstatuty. pttk.pl/Sprawozdanie_PTK_1918.pdf (dostęp: 2.04.2018). 
da Węgrzynowicza ${ }^{15}$. Ten ostatni redagował wymieniony wcześniej „Orli Lot”ogólnopolski periodyk o tematyce krajoznawczej adresowany do młodzieży.

Nauczycielom zaangażowanym w propagowanie wśród uczniów idei krajoznawstwa i regionalizmu starano się pomóc poprzez organizowanie odczytów, kursów, wskazywanie przydatnej literatury i przygotowywanie opracowań o charakterze metodycznym. W publikacjach tego rodzaju, formalizujących wykorzystywanie wycieczek jako formy pracy z młodzieżą, przekazywano nauczycielom i opiekunom dokładne wskazówki o charakterze praktycznym. Nie mniej istotna była warstwa ideowa, mająca przekonać czytelnika do realizowania proponowanych pomysłów i nadawania działaniom znaczenia w wymiarze aksjologicznym. Publikację pionierki dydaktyki geografii, uczącej w krakowskich szkołach średnich - Stanisławy Niemcówny ${ }^{16}$ — zatytułowaną Metodyka pracy w kołach krajoznawczych młodzieży (1921) redakcja „Orlego Lotu” poprzedziła wstępem rozpoczynającym się od słów:

Praca nad poznaniem naszego kraju powinna wyjść z okresu bezplanowości i dorywczości, jaka ją dotychczas cechuje, a ujęta w pewien program dążyć powinna do wyrobienia naszej młodzieży na znających i miłujących swoją ojczyznę obywateli [...]. Metodykę oddajemy w ręce polskich krajoznawców, uważając ją jako podwaliny zorganizowanej pracy krajoznawczej. Niech idzie między wychowawców i młodzieży i niech służy podniesieniu kultury naszej duchowej i dobru naszej zmartwychwstałej i zjednoczonej Ojczyzny ${ }^{17}$.

Sama Niemcówna była zwolenniczką symbiozy edukacji w znaczeniu poszerzania wiedzy z wychowaniem fizycznym, estetycznym i etycznym, dając przykład doskonałego łączenia idei i założeń programowych krajoznawstwa sprzed i po odzyskaniu przez Polskę niepodległości. Na początku poradnika Niemcówna wymieniła zalety uczestnictwa w wycieczkach, zachęcając tym samym nauczycieli do jak najczęstszego korzystania z tej formy pracy:

Przebywanie wśród natury ma odradzające znaczenie dla fizycznego i duchowego zdrowia i rozwoju. Odrywamy się w ten sposób od często szkodliwej lektury i wydostajemy z naszych brudnych miast. Piękno krajobrazów kształci w nas pierwiastek estetyczny i nie pozwala krajoznaw-

15 Zob. B. Boczukowa, Tradycje szkolnego ruchu krajoznawczo-turystycznego w Polsce, Siedlce 2003; A. Czarnowski, Leopold Węrzynowicz — organizator krajoznawstwa wśród młodzieży, Warszawa 1987.

16 Zob. Stanisława Niemcówna - pionier polskiej dydaktyki geografii i krajoznawstwa. Materiały sesji zorganizowanej w piętnasta rocznicę śmierci, red. A. Jelonek, T. Gaweł, Kraków 1976.

17 Redakcja, Praca nad poznaniem naszego kraju..., [w:] S. Niemcówna, Metodyka pracy w kołach krajoznawczych młodzieży, Kraków 1921, s. 3. 
com niszczyć roślinności ani zaśmiecać gór, lecz czyni z nich obrońców przyrody oraz zabytków kultury i pracy ludzkiej ${ }^{18}$.

Kształcenie dostrzegania piękna i postaw etycznych harmonizowało z propagowaniem idei służby ojczyźnie na fundamencie chrześcijańskim. Niemcówna, używając emocjonalnie nacechowanych pytań retorycznych, w młodych ludziach angażujących się w działalność krajoznawczą widziała tych, którzy mają najlepszą sposobność, aby

spojrzeć z bliska na wiele przejawów życia zbiorowego na swych włóczęgach po kraju i świecie Bożym [...] i tym samym pogłębiać własną duszę i sprawność życiową [...]. Przed obcymi nie musieć wstydzić się za poziom naszego życia i za obyczaje ${ }^{19}$.

Książeczkę wydano dzięki wsparciu finansowemu Ministerstwa Wyznań Religijnych i Oświecenia Publicznego (MWRiOP), co utwierdzało potencjalnych odbiorców w traktowaniu jej zawartości jako zgodnej z założeniami polityki oświatowej państwa.

Autorka poradnika już na łamach „Orlego Lotu” ponownie zabrała głos w kwestii przygotowywania wycieczek. Wyróżniła trzy typy wypraw, z których każda mogła przynieść ich uczestnikom wiele korzyści. Pierwszy rodzaj to „drobne" wycieczki, obejmujące najbliższą okolicę, ukierunkowane na lepsze poznanie miejsca życia, pracy, nauki samych wycieczkowiczów. W drugim rodzaju wypraw uczestniczyli wszyscy pragnący zaznajomić się z ,charakterystycznymi krajobrazami Polski”. Jak podkreślała Niemcówna, młodzież uczestnicząca w tych wycieczkach winna poszerzać własne horyzonty poprzez obcowanie z przestrzenią, ludźmi, ich zwyczajami, odmiennymi od tego wszystkiego, z czym obcowała na co dzień. Trzeci rodzaj wypraw, najwartościowszy zarówno pod względem poznawczym, jak i wychowawczym, to wycieczki w mało znane, nieobjęte jeszcze masową turystyką regiony. Bez względu na typ wypraw warunkiem sine qua non było wcześniejsze przygotowanie merytoryczne, ponieważ dawało ono gwarancję rozwijania autentycznej pasji odkrywcy ${ }^{20}$.

Leopold Węgrzynowicz na pierwszym Ogólnopolskim Zjeździe Krajoznawczym w Poznaniu w 1929 roku wygłosił referat o organizacji ruchu krajoznawczego młodzieży szkolnej, w którym obok posiedzeń i przygotowywania referatów wymienił wycieczki jako formę pracy najlepiej przystającą do oczekiwań młodych ludzi i tym samym przynoszącą najlepsze efekty ${ }^{21}$. Wycieczki organizowane przez Stanisławę Niemcównę podawał jako wzór realizowania w praktyce propagowanych dla tej formy założeń, czyli umiejętnego łączenia elementów, które „wyrabia-

18 S. Niemcówna, op. cit., s. 5.

19 Ibidem, s. 20-21.

20 Zob. S. Niemcówna, Wycieczki krajoznawcze, „Orli Lot” 1929, nr 1, s. 2-3.

${ }^{21}$ L. Węgrzynowicz, Organizacja ruchu krajoznawczego młodzieży szkolnej w Polsce, Pierwszy Ogólnopolski Kongres Krajoznawczy w Poznaniu, Sekcja V, Warszawa 1929, http://pbc.gda. pl/dlibra/plain-content?id=5379 (dostęp: 2.04.2018). 
ją spostrzegawczość, zdrowie, hart ducha i ciała"22. W odróżnieniu od wycieczek sportowych, jak podkreślał Węgrzynowicz, krajoznawcze dzięki zbieraniu przez uczniów informacji o faunie, florze, kulturze ludzi mieszkających na danym obszarze dodatkowo „zapalały miłość” do wszystkiego, z czym młodzi ludzie się stykali, co ostatecznie „wzniecało ufność we własne siły i przyszłość narodu”23. Propagowane przez Węgrzynowicza wycieczki wpisywały się zatem w założenia nowego statutu PTK i jednocześnie, zwłaszcza na płaszczyźnie wychowawczej, realizowały w praktyce postulaty $\mathrm{MWRiOP}^{24}$.

Jak wspomniano, metodykę Niemcówny sygnował „Orli Lot” — książka krakowskiej nauczycielki geografii stała się w konsekwencji pierwszym tomem serii wydawniczej „Biblioteka »Orlego Lotu«”, której powołanie do życia ogłoszono w numerze 12 pisma. Węgrzynowicz starał się, aby kierowany przez niego miesięcznik został włączony na stałe w zbiór rekomendowanych przez MWRiOP publikacji adresowanych zarówno do nauczycieli, jak i uczniów ${ }^{25}$. Pedagodzy mogli dzięki temu wykorzystywać „Orli Lot” jako uzupełnienie podręczników, których - przynajmniej w pierwszych latach powojennych - bardzo brakowało. Uczniom czasopismo dostarczało z kolei interesującej lektury, ale było też dla nich platformą wypowiedzi, dawało możliwość zaprezentowania ich działalności w ramach kół krajoznawczych.

Popularyzowaniu wycieczek z udziałem młodzieży szkolnej służyły dwa rodzaje wypowiedzi drukowanych na łamach „Orlego Lotu”. Jedną grupę stanowiły liczne artykuły poświęcone prezentowaniu walorów krajoznawczych poszczególnych regionów, w tym gór, autorstwa uznanych geografów, etnografów, na przykład Ludomira Sawickiego, Mieczysława Orłowicza, podkreślających również szczególną rolę wycieczek w wychowaniu społeczno-etycznym. Drugą grupę tworzyły sprawozdania, relacje, niejednokrotnie autorstwa uczniów biorących udział w wyprawach, które z jednej strony można traktować jako dowód skuteczności stosowanych przez wychowawców form pracy. Z drugiej strony wypowiedzi tego typu były narzędziem niwelowania dystansu między nadawcą-dorosłym, czyli wydawcą, redaktorem pisma, a docelowym adresatem — młodymi ludźmi. Teksty nadsyłane przez rówieśników miały w sobie większą siłę oddziaływania, ponieważ dawały młodzieży poczucie wspólnoty doświadczeń i jednocześnie były przykładem poważnego traktowania przez dorosłych oraz swoistego rodzaju partnerstwa w eksploracji górskiej przestrzeni.

Artykuły teoretyczne wypełniały funkcję edukacyjną i zgodnie z metodycznymi założeniami organizowania wycieczek ich lektura pomagała już na wstęp-

22 Ibidem, s. 4.

23 Ibidem.

24 Zob. Statut Polskiego Towarzystwa Turystyczno-Krajoznawczego, Warszawa 1935, s. 6, § 5 pkt p; s. 29-30, § 55, http://bstatuty.pttk.pl/Statut_PTK_1935.pdf (dostęp: 2.04.2018).

${ }^{25} \mathrm{Na}$ łamach pisma informowano o rozporządzeniach wydawanych między innymi przez MWRiOP, zalecających dyrekcjom szkół prenumeratę „Orlego Lotu” oraz zakładanie szkolnych kół krajoznawczych; zob. Reskrypt MWRiOP, „Orli Lot” 1921, nr 3, s. 47; Okólnik Komisji Szkolnej Księstwa Cieszyńskiego, „Orli Lot” 1921, nr 12, s. 148. 
nym etapie przygotowań do wyprawy. Informacje w nich zawarte mogły okazać się przydatne zwłaszcza w wypadku obozów i wypraw górskich, które uznawano za szczególnie wymagające.

Adam Gadomski, geolog i glacjolog, przybliżał młodym czytelnikom topografię Tatr, wymieniając nazwy szczytów oraz wprowadzając specjalistyczną terminologię z zakresu geomorfologii czy glacjologii, jak żleb, stożki rzeczno-lodowco$w^{26}$. Na łamach „Orlego Lotu” drukowano też artykuły dotyczące ukształtowania górskiego terenu, w tym form, o których ze względu na trudności w eksploracji rzadko pisano, jak jaskinie ${ }^{27}$. Teksty tego rodzaju zdaniem redakcji wyposażały młodych ludzi w niezbędną i potrzebną wiedzę, aby móc podjąć samodzielne wyprawy. Współpracownicy pisma starali się, żeby ich wypowiedzi podporządkowane w pierwszej kolejności funkcji edukacyjno-poznawczej nie przypominały jednak podręcznikowych tekstów obciążonych lekturowym przymusem. Jednym z najczęstszych zabiegów pozwalających na ukrycie edukacyjnej misji było użycie narracji pierwszoosobowej, sytuującej autora w roli autentycznego, naocznego świadka, należącego w danym momencie do opisywanej przestrzeni. Przyjęcie takiej perspektywy można uznać nie tylko za trafną decyzję dotykającą zagadnień dziennikarskich, lecz także decyzję naturalną, jeżeli wziąć pod uwagę biografie autorów, którzy byli znawcami gór i zarazem prawdziwymi pasjonatami górskich wędrówek, taternictwa czy speleologii. Dla odbiorców pisma relacje z autentycznych wypraw, dzięki przyjętej formule nadającej warstwie poznawczej ekspresji cechującej przeżywanie przygody, z pewnością mogły wydawać się czytelniczo atrakcyjniejsze.

Wśród relacji i sprawozdań drukowanych na łamach „Orlego Lotu” nie zabrakło klasycznego tekstu Tytusa Chałubińskiego Sześć dni w Tatrach. Wycieczka bez programu $^{28}$. Znawcy zagadnień krajoznawczych, w tym problematyki górskiej, w relacjach z wypraw eksponowali entuzjazm wyzwalany przez kontakt z wyjątkową w swoim rodzaju przestrzenią. W obrazie krajobrazu Doliny Białej Wody Kazimierza Dobrowolskiego dominowały epitety superlatywne, których nagromadzenie służyło nadaniu konkretniej przestrzeni cech odróżniających ją od innych terenów i utrwaleniu takiego wyobrażenia w świadomości czytających. Opis Doliny Białej Wody przedstawionej jako „drogocenna perła Tatr, jeden z najdzikszych i najbardziej porywających niewypowiedzianym urokiem wąwozów górskich"29, będący przykładem emotywnej topografii korespondującej z estetycznymi kategoriami wzniosłości i piękna, miał wywoływać u młodych czytelników uczucie

26 Zob. A. Gadomski, Dolina Jaworowa, „Orli Lot” 1924, nr 4, s. 53-58; idem, Dolina Białej Wody, „Orli Lot” 1924, nr 2, s. 23-27; idem, Jura Krakowska jako teren wycieczek krajoznawczych, „Orli Lot” 1920, nr 1, s. 6-7.

27 Zob. M. Gotkiewicz, Grota „Olejarnia” w Dolinie Chochołowskiej, „Orli Lot” 1924, nr 10, s. $156-157$.

28 T. Chałubiński, Sześć dni w Tatrach. Wycieczka bez programu. (Przedruk z „Pamiętnika Towarzystwa Tatrzańskiego. Poprzedził wstępem Jaz.), „Orli Lot” 1921, nr 4, s. 56-60; nr 6, s. 89-92; nr 7, s. 105-107; nr 8-10, s. 121-123; nr 12, s. 150-153; 1922, nr 2, s. 24-26.

${ }^{29}$ K. Dobrowolski, Ze wspomnień jaworzyńskich, „Orli Lot” 1922, nr 2, s. 18. 
nie tyle zachwytu, ile wiary we własne siły: „Tu czar gór w duszę płynący podnosi skrzydła do górnych lotów i zamierzeń" ${ }^{30}$.

Socjo-przestrzenną mediację ilustrowały w szczególny sposób wypowiedzi, których autorzy punktem wyjścia do oddania słowami swoich emocji czynili doświadczenie wzrokowe. W rejestracji wzrokowego postrzegania przestrzeni górskiej ważną rolę odgrywał kolor. Tadeusz Kiełpiński relację z wyprawy w Tatry rozpoczynał od opisu zachodu słońca i zmian w postrzeganiu górskiego krajobrazu pod wpływem światła. W ostatnich promieniach słońca stoki „bledły”, świerkowe lasy „ciemniały”, a skały przybierały kolor srebra, mgły, rozbłyskując na krótkie chwile czerwienią ${ }^{31}$. Autor wypowiedzi doznania wzrokowe połączył z zapisem elementów krajobrazu dźwiękowego:

— Jak cicho... jak tu bardzo, bardzo cicho... [...] Cisza górskiego pustkowia, dźwięczała w uszach szumem potoku, płynącego gdzieś w dołach, hen... Siedzieliśmy na szczycie Małej Wysokiej, odpoczywając po długiej i uciążliwej drodze zapatrzeni w dal, wsłuchani w odległe poszumy halne, w szepty kosodrzewiny, które chwilami wiatr z ponad dalekich śpiących stanów przynosi1 ${ }^{32}$.

Owej zmysłowej wizualizacji towarzyszyły emocje, które następnie posłużyły do waloryzowania przestrzeni jako czynnika wpływającego na kształtowanie kondycji człowieka w wymiarze fizycznym i etycznym. $Z$ dalszej części relacji Kiełpińskiego czytelnik dowiedział się, że wyjątkowych doznań w relacji z opisywaną wcześniej górską przestrzenią mogli doświadczyć tylko wybrani. Autentyczny miłośnik i znawca Tatr - taternik — porzucał, jak pisał autor, ,gwarne schroniska, wygodne utarte szlaki wycieczkowe pełne »partii« turystów, wrzasku, arogancji, puszek od konserw i całej tej specyficznej »cywilizacji «"33. Krytyczne opinie o przejawach turystyki masowej, między innymi o rozbudowywanej infrastrukturze turystycznej, zderzono z opisami wędrówki w te partie gór, które ze względu na ukształtowanie terenu były jeszcze niedostępne dla przeciętnego turysty. Zabieg kontrastu ostatecznie służył waloryzacji konkretnego sposobu obcowania z górską przestrzenią: „Trudności górskich dróg, to, co mieści w sobie cały urok wycieczek, owo pokonywanie przestrzeni i niebezpieczeństw siłą i sprawnością swych mięśni" 34.

Podobny rodzaj sfunkcjonalizowanego opisu krajobrazu górskiego postrzeganego w trakcie wędrówki występował w artykułach na temat wypraw w Beskidy Zachodnie, Gorgany, pasmo Czarnohory. Marian Gotkiewicz podczas wspinaczki na Babią Górę, podobnie jak Kiełpiński w Tatrach, nie szedł znanymi i obleganymi przez turystów szlakami. Docierał na szczyt samotnie i doświadczał uczuć

\footnotetext{
${ }^{30}$ Ibidem.

31 T. Kiełpiński, Ponad tatrzańskie turnie..., „Orli Lot” 1924, nr 2-3, s. 27-31; nr 4-5, s. 58-66.

32 T. Kiełpiński, Ponad tatrzańskie turnie..., „Orli Lot” 1924, nr 2-3, s. 27-28.

33 Ibidem, s. 28.

${ }^{34}$ Ibidem, s. 30
} 
opisanych później przy pomocy takich samych środków wyrazu jak we wcześniej prezentowanej wypowiedzi. Zastosowana paleta barw składała się z odcieni bieli, srebra, czerwieni. Autor kreślił obraz krajobrazu, wykorzystując epitety, porównania odzwierciedlające doznania wzrokowe oraz dźwiękowe, a w tych ostatnich dominowała cisza ${ }^{35}$. Opis percepcji sensorycznej wpisywał się w ramę kulturową, którą stanowiły teksty literackie. Kulturowe zapośredniczenia występowały w dwóch podstawowych wersjach. Autorzy, pisząc o swoich doznaniach wywołanych kontaktem z górską przestrzenią, wykorzystywali figury, ujęcia utrwalone w tekstach literackich epok wcześniejszych. Relacje z wędrówek, opisy pasm czy widoków rozpościerających się ze szczytów komponowane były z urbanistycznych, batalistycznych ujęć, zabiegów animizujących, symboliki akwatycznej, czyli ze środków wyrazu typowych dla romantycznych utworów ${ }^{36}$. Autorzy tekstów „Orlego Lotu” często sięgali także po zabiegi sakralizujące przestrzeń, wzorując się na przykład na młodopolskiej poezji. Drugim sposobem ujmowania osobistych doznań w szersze ramy kulturowe, co ułatwiało podporządkowanie wypowiedzi celom pozaliterackim (na przykład wychowawczym), było cytowanie tytułów lub fragmentów konkretnych utworów. Gotkiewicz, patrząc na panoramę Tatr o zachodzie słońca, śpiewał pierwszą zwrotkę Roty spisko-orawskiej Stanisława Eliasza Radzikowskiego. Czyn ten nadaje jego wędrówce znamion swoistego rodzaju patriotycznej pielgrzymki ${ }^{37}$.

W większości relacji z górskich wycieczek autorstwa taterników i nauczycieli regionalistów dominował ton powagi, a w partiach będących emocjonalnie nacechowanymi opisami danego obszaru geograficznego nawet patetyczny. Redakcja nie zapominała jednak o potrzebach i oczekiwaniach docelowego adresata pisma, dlatego zamieszczano również wypowiedzi, w których na pierwszy plan wysuwano kategorię przygody i humor. Opis przedstawiający wędrówkę ujmowaną w znaczeniu rywalizacji, sprawdzianu umiejętności, dowodu sprawności i odwagi mógł być bowiem szczególnie atrakcyjny dla młodych ludzi. Jan Sławiczek, kursant seminarium nauczycielskiego w Bobrku koło Cieszyna, w pamięci swoich kolegów zapisał się jako utalentowany rysownik, śpiewak, znawca najnowszej literatury i człowiek pełen optymizmu ${ }^{38}$. Sławiczek humorystycznie opisał swoją pierwszą wyprawę w Tatry, z której relację wydrukowano na łamach „Orlego Lotu” w 1928 roku $^{39}$. Mimo że powód, jaki skłonił go do wyruszenia w góry — zakład z kolegą

35 Zob. M. Gotkiewicz, Z wycieczek w polskie góry, „Orli Lot” 1922, nr 9, s. 131-134.

36 Por. J. Kolbuszewski, Tatry romantyczne, [w:] idem, Tatry. Literacka tradycja motywu gór, Kraków 1995, s. 27-53.

37 Należy dodać, że redakcja „Orlego Lotu” od początku istnienia pisma silnie akcentowała konieczność włączenia w granice państwa polskiego jak największego obszaru Tatr Wysokich, Orawy i Śląska Cieszyńskiego; zob. K. Sosnowski, Krajoznawczy rzut oka na Spisz i Orawę, „Orli Lot” 1920, nr 3, s. 20-24; W. Semkowicz, Śladami kultury polskiej na Spiszu, „Orli Lot” 1920, nr 3, s. 24-26.

38 J. Broda, Skoczowski tułacz Jan Stawiczek-Kowalik, http://skarbnica.ox.pl/94,skoczowskitulacz-jan-slawiczek-kowalik.html (dostęp: 4.04.2018).

39 J. Sławiczek, Wrażenia z Tatr, „Orli Lot” 1928, nr 3, s. 62-68; nr 4, s. 79-81. 
o 10 złotych — nie przystawał do propagowanych idei mających przyświecać organizowaniu wycieczek, to z pewnością odzwierciedlał młodzieńczy entuzjazm i dezynwolturę. Sławiczek górską przestrzeń znaną mu tylko z lektur i fotografii przedstawiał, aby posłużyć się terminologią Paula Rodawaya, za pomocą narzędzi wizualnych ${ }^{40}$. Autor nakładał swoje wcześniejsze wyobrażenia na rezultaty postrzegania sensorycznego i dokonywał aktu identyfikacji topograficznej. Rozpoznawał gatunki roślin, nazwy dolin, hal, szczytów:

Nieco wyżej na karczowisku, jakby odbicie błękitu, modrym kobiercem słały się ostróżki tatrzańskie (Delphinium oxysepalum). Na oglądaniu tych znanych mi tylko z botaniki okazów zeszła mi droga na Boczań [...]. Zagadałem pierwszego z brzegu o potrzebne informacje i za kwadrans byłem na Hali Gąsienicowej. Poznałem ją zaraz. Tyle przecie widoków i obrazków przedstawiających ją oglądałem. To polski „Pan Fudżi” krajobrazów tatrzańskich ${ }^{41}$.

Im wyżej wspinał się bohater tekstu, tym częściej w jego relacji pojawiały się opisy emocji wzmocnione przywoływaniem tekstów literackich. Nad Czarnym Stawem przypomniał sobie wiersz pod tym samym tytułem Maryny Wolskiej i identyfikował się w wymiarze uczuciowym z podmiotem lirycznym. Refleksyjne, nostalgiczne w tonacji (ponieważ noc spędzona w górach zrodziła u bohatera tęsknotę za rodzinnym Śląskiem) fragmenty relacji przeplatały się z pełnymi humoru charakterystykami spotkanych w schroniskach osób. Sławiczek chwalił bezpośredniość, życzliwość osób wędrujących po górach, będąc przekonanym, że to obcowanie z konkretną przestrzenią — górską — wpływało na zachowanie ludzkie i wydobywało z człowieka jego najlepsze cechy. On sam kończył relację wyznaniem neofity:

Dwie masz Polsko świątynie: Bałtyk i Tatry. Pierwszą pokochałem, kiedy w noc baśni, w noc cudu, polską, księżycową zamieniała się na ruchliwą, szczerozłotą taflę, drugą: gdy poszarpane mgliska, gnane wichrem czepiały się zawrotnych urwisk, kiedy ostatni pocałunek słońce kładło na wyniosłym czole turni i kiedy góral z szczerego serca swojego powiedział: „To na Kasprowiczów grób, panie!”42.

Na łamach „Orlego Lotu” publikowano także relacje samych uczniów biorących udział w wyprawach. Uczeń ósmej klasy gimnazjum matematyczno-przyrodniczego w Poznaniu (M. Laskowski), pisząc o wrażeniach z wycieczki do Zakopanego w sierpniu 1921 roku, używał licznych superlatywów. Tatry zarówno dla niego, jak i dla wielu uczniów widzących góry pierwszy raz w życiu, są „piękne”, „najpiękniejsze”. Widoki ze szczytów „zachwycają”, Morskie Oko jest „cudowne”, a wędrowcy „czują się jak w bajce”. Kontakt z krajobrazem tak innym od tego,

40 P. Rodaway, Sensuous Geography, London 1994, s. 116.

41 J. Sławiczek, Wrażenia z Tatr, „Orli Lot” 1928, nr 3, s. 63-64.

42 Ibidem, s. 81. 
którego na co dzień doświadczał, oraz fachowe, obszerne objaśnienia opiekunów wywołały u korespondenta falę uczuć patriotycznych, co znalazło odzwierciedlenie w wykrzyknieniach typu ,Zaiste piękne są te nasze polskie Tatry!” i w zakończeniu potwierdzającym korzyści nie tylko poznawcze, jakie przyniosła wyciecz$\mathrm{ka}$, ale też niezapomniane doznania emocjonalne ${ }^{43}$.

Dziewczęta uczestniczące w wycieczkach organizowanych i prowadzonych przez Stanisławę Niemcównę dostarczały do „Orlego Lotu” relacje w formie wzorcowo realizującej metodyczne wytyczne krakowskiej nauczycielki. Uczennice opisywały każdy dzień, koncentrując się przede wszystkim na informacjach topograficznych oraz historyczno-antropologicznych. Biorąc jednak pod uwagę cele, jakie Niemcówna wyznaczała wycieczkom, w sprawozdaniach znalazły się także fragmenty dowodzące wpływu tej formy pracy na charakter uczestniczek i ich poczucie estetyczne:

Dzień ten najbardziej zapisał się w naszej pamięci jako ostatni dzień wycieczki, pełen wrażeń niezapomnianych! Bo czyż którakolwiek z nas zapomni chwile, kiedy stanąwszy na przełęczy, zobaczyła przed sobą cudowną panoramę ośnieżonych Tatr i gdy poczuła mroźny wiew, bijący od białego całunu? A potem znowu przecudowny widok z Trzech Koron na Tatry, Gorce, Babią oraz na część Karpat, znajdującą się po słowackiej stronie! ${ }^{44}$

Relacje uczniów kończyły się zazwyczaj wyrażeniem żalu z powodu zakończenia przygody, jaką była górska wędrówka. Charakterystyczną cechą tych wypowiedzi, dowodzącą przejmowania $\mathrm{z}$ tekstów autorów profesjonalnych wzorców służących opisywaniu zjawisk mieszczących się w obrębie topografii emotywnej, było wprowadzenie motywu patriotyzmu: „Została za nami hen, daleko, Howerla... Tylko jej obraz niezatarty, głęboko ukryty w sercach naszych poniesiemy do ojczystych pól i dolin. Żegnaj Howerlo!"45.

Podobnego rodzaju sprawozdania zamieszczał „Młody Krajoznawca Śląski”’46. Czasopismo oprócz treści poznawczo-edukacyjnych, co było wyznacznikiem pism krajoznawczych, akcentowało w szczególny sposób problematykę patriotyczną. Pedagodzy pracujący w województwie śląskim zwracali bowiem uwagę na rolę szkoły oraz organizacji zrzeszających młodzież w aktywizacji mieszkańców Śląska na rzecz integracji regionu z innymi dzielnicami Polski. Cel ten wyartykułowano w tekście programowym, pisząc: „Chcemy poznać naszą okolicę, nasz region, bo tylko wtedy, gdy dokładnie się z nim zapoznamy, uświadomimy sobie z całkowitą jasnością te wszystkie węzły, jakie nasz region łączą z całą Polską" ${ }^{\text {"47 }}$.

43 M. Laskowski, Wycieczka uczniów gimnazjów poznańskich do Krakowa, Wieliczki i Zakopanego, „Orli Lot” 1921, nr 11, s. 139-141.

44 Z. Hoszowska, Dolina Dunajca. Przebieg wycieczki, „Orli Lot” 1929, nr 1, s. 7.

45 KAM., Wycieczka w okolice Czarnohory, „Orli Lot” 1925, nr 8, s. 118.

46 Zob. H. Synowiec, Śląkie czasopisma szkolne (1922-1939), Katowice 1999.

47 Przystępujemy do wydawania..., „Młody Krajoznawca Śląski” 1934, nr 1, s. 1-2. 
W 1937 roku w trzech kolejnych numerach wydrukowano obszerne sprawozdanie z wycieczki w Beskidy Zachodnie, które zawierało wiele szczegółowych informacji o historii, zabytkach przemyśle Bielska ${ }^{48}$. Na młodym korespondencie miasto zrobiło wrażenie swoją organizacją, rozmachem, dynamizmem, ale — zgodnie z ideami krajoznawstwa - to obcowaniu z przyrodą przypisywał właściwości pozwalające docenić pracę człowieka czy zauważyć jego potrzeby, między innymi estetyczne. Będąc w górach, młodzi ludzie doznawali uczuć, które zapadały im głęboko w pamięć:

Góry dały nam wiele wrażeń, dały nam wypoczynek i dodały nam nowych sił do dalszej pracy szkolnej. Do końca życia nie zapomnimy pięknych widoków gór, majestatycznie wznoszących się nad całą okolicą, nie zapomnijmy chat góralskich, tak miłych, choć niekiedy ubogich, tych prześlicznych ubiorów ludowych, tych kościółków i innych zabytków, nie zapomnimy... ${ }^{49}$

Z opisu wycieczki, w trakcie której uczniowie zdobywali Klimczok, Skrzyczne, Baranią Górę, Malinowską Skałkę, Pilsko, zwiedzali okoliczne miejscowości — oprócz Bielska były to: Bystra, Szczyrk, Wisła, Ustroń, Milówka, Jeleśnia, Żywiec — przebijało poczucie dumy z bycia Polakiem i przekonanie, że źródłem polskiej tożsamości narodowej, wbrew widocznym śladom obecności niemieckiej kultury, jest region, z którego pochodzą. W relacjach z obozów, wędrówek w inne rejony Polski, na przykład na Podkarpacie, także podkreślano atrybuty składające się na zakres tematyczny słowa „polskość”. Dziewczęta z chorzowskiego gimnazjum, opisując zwiedzaną wieś Haczów w województwie lwowskim, eksponowały udział mieszkańców wsi w walkach w trakcie I wojny światowej i ofiarę z własnego życia, jaką złożyli za wolność Polski ${ }^{50}$.

W artykule wstępnym dwutygodnika „Młody Taternik” ${ }^{2}$, stylizowanym na list adresowany do młodzieży, można przeczytać wzniosłe cele stawiane przed młodymi czytelnikami. Tekst ten to odbicie systemu imponderabiliów wchodzących w skład piłsudczykowskiej ideologii. Za ową stałą, niezmienną wartość rządzący obóz uznawał niepodległe państwo, przeżywane emocjonalnie jako byt, któremu podporządkowane są działania jego mieszkańców. Redakcja czasopisma perswadowała:

„Taternik” służyć będzie wyłącznie Waszym celom, wykształci Was już w ławie szkolnej na dobrych obywateli państwa, zasiewając na żyznych niwach Waszych dusz zdrowe ziarno cnót obywatelskich, poszanowania pracy i obowiązku, czci dla bohaterów-żołnierzy, głównie dla uosobienia i wcielania wszechpotężnej Idei Państwowej Pierwszego Marszałka

48 Gł.-Pol.-Now., Z wycieczki wakacyjnej w Beskidy Zachodnie, cz. 1, „Młody Krajoznawca Śląski” 1937, nr 1, s. 13-16; cz. 2, nr 2, s. 7-9; cz. 3, nr 3, s. 11-13.

49 G1.-Pol.-Now., Z wycieczki wakacyjnej..., cz. 3, s. 13.

50 Sowińska, Z letniej wędrówki, „Młody Krajoznawca Śląski” 1937, nr 3, s. 6-8.

51 Por. M. Pinkwart, Prasa zakopiańska w latach 1891-1939, Kraków 2016, s. 245-246. 
Polski Józefa Piłsudskiego [...]. Odblask i piękno podtatrzańskej krainy oświetlić musi, a echo pieśni podhalańskiej oczarować resztę Polski! A więc dalej do pracy! ${ }^{52}$

Romantyczne przeżywanie gór, postrzeganie krajobrazu w kategoriach estetyczno-etycznych, cechujące wypowiedzi (zwłaszcza uczniów) drukowane w „Młodym Taterniku”, korespondowały z ideami Wielkiej Polski głoszonymi przez obóz piłsudczykowski. Tadeusz Mroczkowski, uczeń ósmej klasy gimnazjalnej, poetycko opisywał swoje wrażenia na widok Tatr o różnych porach roku gór, które: „Zawsze te same i zawsze inne. Te same, bo nie zmieniają się zarysy gór, inne, bo inaczej przemawiają do nas, inne wywołują uczucia i inne w nas budzą wrażenia Tatry w słońcu, Tatry we mgle, Tatry w śniegu"53. Obcowanie z przyrodą, roztaczającymi się przed wędrowcami niepowtarzalnymi widokami, staje się źródłem przeżyć mistycznych, poczucia bliskiego obcowania z przestrzenią owianą, jak pisał ów młodzieniec, ,oddechem Wielkiego Budowniczego”, „Twórcy Wszechświata" 54 . Zabieg sakralizacji Tatr służył kreowaniu obrazu regionu z Zakopanem jako wyjątkowego miejsca w Polsce, jako „nieocenionego skarbu naszego państwa", zapewniającego wszystkim tu przybyłym wzmocnienie sił witalnych i niezapomniane wrażenia ${ }^{55}$.

Redakcje młodzieżowych czasopism krajoznawczo-turystycznych kładły nacisk na funkcje poznawczo-wychowawcze drukowanych wypowiedzi, upatrując w wycieczkach narzędzie służące wzbogaceniu wiedzy młodych ludzi i jednocześnie kształcące pożądane społecznie postawy etyczne. Artykuły o charakterze edukacyjnym, relacje i opisy górskich wycieczek pióra znawców gór, ale też młodych ludzi, drukowane na łamach pism krajoznawczo-turystycznych stanowiły przykłady wypowiedzi operujących przede wszystkim słowem. Redaktorzy pism perswazyjność tych tekstów wzmacniali poprzez dołączanie materiału ikonicznego w formie wykresów, szkiców, map i zdjęć. Szczególnie fotografie mogły przyciągnąć uwagę czytelników. Wybierano przede wszystkim zdjęcia przedstawiające najwyższe szczyty, wymienione także w relacjach, na przykład Babią Górę, Zamarłą Turnię, rozbudzając w ten sposób ciekawość, zwłaszcza czytelników z regionów niegórskich. Przede wszystkim w czasopismach mających charakter ogólnopolski, jak „Orli Lot”, połączenie elementów tekstowego i ikonicznego tworzyło przekaz sprawnie podporządkowany regułom wypowiedzi perswazyjnej, realizującej zadanie kształtowania „nowego” człowieka — człowieka pełnego witalizmu, kierującego się w życiu czytelnym i klarownym systemem wartości etycznych, u którego podstaw leżały idee chrześcijańskie i państwowe propagowane przez instytucje wychowawczo-edukacyjne II Rzeczypospolitej.

\footnotetext{
52 Słowo od Wydawnictwa. Kochana Młodzieży!, „Młody Taternik” 1934, nr 1, s. 2.

53 T. Mroczkowski, Tatry, „Młody Taternik” 1934, nr 1, s. 10.

54 Ibidem, s. 11

55 Przyjedźcie do Zakopanego, „Młody Taternik” 1934, nr 4, s. 10-11.
} 


\section{Bibliografia}

Boczukowa B., Tradycje szkolnego ruchu krajoznawczo-turystycznego w Polsce, Siedlce 2003.

Broda J., Skoczowski tułacz Jan Stawiczek-Kowalik, http://skarbnica.ox.pl/94,skoczowski-tulacz-jan-slawiczek-kowalik.html.

Chałubiński T., Sześć dni w Tatrach. Wycieczka bez programu. (Przedrukz „,Pamiętnika Towarzystwa Tatrzańskiego. Poprzedzit wstępem Jaz.), „Orli Lot” 1921, nr 4, 6, 7, 8-10, 12; 1922, nr 2.

Chudziński E., Skoczek T., Regionalizm. Idea - ludzie - instytucje, Warszawa 2013.

Czarnowski A., Leopold Węrzynowicz - organizator krajoznawstwa wśród młodzieży, Warszawa 1987.

Dobrowolski K., Ze wspomnień jaworzyńskich, „Orli Lot” 1922, nr 2.

Gadomski A., Dolina Biatej Wody, „Orli Lot” 1924, nr 2.

Gadomski A., Dolina Jaworowa, „Orli Lot” 1924, nr 4.

Gadomski A., Jura Krakowska jako teren wycieczek krajoznawczych, „Orli Lot” 1920, nr 1.

Gł.-Pol.-Now., Z wycieczki wakacyjnej w Beskidy Zachodnie, cz. 1-3, „Młody Krajoznawca Śląski” 1937, $\mathrm{nr} 1,2,3$.

Gotkiewicz M., Grota „Olejarnia” w Dolinie Chochołowskiej, „Orli Lot” 1924, nr 10.

Gotkiewicz M., Z wycieczek w polskie góry, „Orli Lot” 1922, nr 9.

Hoszowska Z., Dolina Dunajca. Przebieg wycieczki, „Orli Lot” 1929, nr 1.

Jarowiecki J., Czasopisma dla dzieci i młodzieży oraz prasa młodzieżowa w Polsce w latach 19182000, Kraków 2016.

Kabzińska Ł., Idea wychowania moralno-społecznego w programach Międzynarodowych Kongresów Pedagogicznych okresu międzywojennego, „Warmińsko-Mazurski Kwartalnik Naukowy, Nauki Społeczne" 2013, nr 4.

KAM., Wycieczka w okolice Czarnohory, „Orli Lot” 1925, nr 8.

Kiełpiński T., Ponad tatrzańskie turnie..., „Orli Lot” 1924, nr 2-3, 4-5.

Kolbuszewski J., Tatry. Literacka tradycja motywu gór, Kraków 1995.

Laskowski M., Wycieczka uczniów gimnazjów poznańskich do Krakowa, Wieliczki i Zakopanego, „Orli Lot” 1921, nr 11.

Lubczyńska A., Regionalizm kielecki w latach 1918-1939, Kielce 2008.

Mroczkowski T., Tatry, „Młody Taternik” 1934, nr 1.

Nawroczyński B., Tempo rozwoju społecznego a zadania wychowawcze pokolenia, „Muzeum” 42, 1927, nr 1-2.

Nawroczyński B., Teoria i praktyka wychowania, „Przegląd Pedagogiczny” 42, 1923, nr 1.

Niemcówna S., Metodyka pracy w kołach krajoznawczych młodzieży, Kraków 1921.

Niemcówna S., Wycieczki krajoznawcze, „Orli Lot” 1929, nr 1.

Niewczas M., Zaborniak S., Szmyd Ł., Historia turystyki w Polsce przed 1939 rokiem, t. 1. Tradycje, prekursorzy, prawo, szlaki i upowszechnianie, Rzeszów 2017.

Niewczas M., Zaborniak S., Szmyd Ł., Historia turystyki w Polsce przed 1939 rokiem, t. 2. Organizacje i stowarzyszenia turystyczne, Rzeszów 2017.

Okólnik Komisji Szkolnej Księstwa Cieszyńskiego, „Orli Lot” 1921, nr 12.

Patkowski A., Idee przewodnie regionalizmu, „Przegląd Współczesny” 11, 1924, nr 30.

Patkowski A., Projekt organizacji Uniwersytetu Powszechnego imienia Stanisława Konarskiego dla nauczycielstwa szkół powszechnych i średnich oraz pracowników społecznych i samorzadowych, „Oświata Pozaszkolna” 1923, nr 1.

Pinkwart M., Prasa zakopiańska w latach 1891-1939, Kraków 2016.

Polskie Towarzystwo Krajoznawcze, Sprawozdanie za rok 1918, http://bstatuty.pttk.pl/Sprawozdanie_PTK_1918.pdf.

Przyjedźcie do Zäkopanego, „Młody Taternik” 1934, nr 4. 
Przystępujemy do wydawania..., „Młody Krajoznawca Śląski” 1934, nr 1.

Reskrypt MWRiOP, „Orli Lot” 1921, nr 3.

Rodaway P., Sensuous Geography, London 1994.

Rybicka E., Geopoetyka. Przestrzeń i miejsce we wspótczesnych teoriach i praktykach literackich, Kraków 2014.

Semkowicz W., Śladami kultury polskiej na Spiszu, „Orli Lot” 1920, nr 3.

Sławiczek J., Wrażenia z Tatr, „Orli Lot” 1928, nr 3, 4.

Słowo od Wydawnictwa. Kochana Młodzieży!, „Młody Taternik” 1934, nr 1.

Socha I., Czasopisma dla młodzieży — literatura piękna — wychowanie literackie (1918-1939), Katowice 1990.

Sosnowski K., Krajoznawczy rzut oka na Spisz i Orawę, „Orli Lot” 1920, nr 3.

Sowińska, Z letniej wędrówki, „Młody Krajoznawca Śląski” 1937, nr 3.

Stanisława Niemcówna - pionier polskiej dydaktyki geografii i krajoznawstwa. Materiaty sesji zorganizowanej w piętnasta rocznicę śmierci, red. A. Jelonek, T. Gaweł, Kraków 1976.

Statut Polskiego Towarzystwa Turystyczno-Krajoznawczego, Warszawa 1935, http://bstatuty.pttk. pl/Statut_PTK_1935.pdf.

Strzelecki M., Wizje wychowania społecznego w polskiej myśli politycznej lat 1918-1939, Bydgoszcz 2008.

Synowiec H., Śląskie czasopisma szkolne (1922-1939), Katowice 1999.

Ustawa Polskiego Towarzystwa Krajoznawczego, Warszawa 1906.

Węgrzynowicz L., Organizacja ruchu krajoznawczego młodzieży szkolnej w Polsce, Pierwszy Ogólnopolski Kongres Krajoznawczy w Poznaniu, Sekcja V, Warszawa 1929, http://pbc.gda. $\mathrm{pl} / \mathrm{dlibra} /$ plain-content?id=5379.

Wójcik Z., Aleksander Patkowski - pionier regionalizmu turystyczno-krajoznawczego w Polsce, Radom 2003.

Wysocka B., Regionalizm wielkopolski w II Rzeczypospolitej 1919-1939, Poznań 1981. 